\title{
The conflict of values in the context of acceptance of multiculturalism
}

\section{KEYWORDS}

value conflict, multiculturalism, assertiveness, boundaries of self

\begin{abstract}
There is a quite big progress in the area of education on acceptance and tolerance towards multiculturalism. The main supporter of politics of multiculturalism is Will Kymlicka, and therefore I refer to his thoughts in this essay. However, in contemporary socio-cultural situation of Western civilization, we need something more than the mere acceptance of cultural diversity. It is worth promoting educational programmes that include themes related to the raising of citizens' awareness of boundaries of self - both in the individual and group aspect. At the same time majority groups should be supported by some tools that would help them to protect their identities without harming others.
\end{abstract}

The increasing cultural diversity, which becomes more intense due to increasingly stronger migrations resulting from various social phenomena, sets more and more serious challenges related to the acceptance of diversity. The humanistic discussion of the turn of the $21^{\text {st }}$ century was characterised by substantial pressure on the promotion of the idea of multiculturalism and its promotion with an acceptance-oriented approach. At the end of the $20^{\text {th }}$ century, two basic approaches to the positive perception of cultural diversity appeared: the descriptive approach and the postulative approach. The descriptive approach was aimed at describing the phenomenon of cultural differentiation in the context of specific features of postmodern societies: mobile, heterogeneous and based on the development of technology. Within the scope of this trend, mobility processes, motives for migration, the state of cultural diversity of the community and trends in changes of this diversity were examined and described. The postulative trend openly promoted cultural diversity as a desired state that should be accepted or even stimulated with regard to its development. This second approach bears a clear axiological message and is an expression of a priori assumptions concerning the positive assessment of phenomena related to cultural diversity 
(cf. Kymlicka 1995, 1998). Unfortunately, this second approach, however desirable it might seem, may easily slide towards the paradoxical promotion of ethnocentric attitudes: advocating the need to accept a certain state of affairs is equally dangerous in the case of promotion of homogeneity and promotion of heterogeneity. While the substance of the process changes, the process itself remains identical: it assumes the lack of acceptance for a different point of view (cf. Burszta 1995, Kmita 1995, Rorty 1991, Rorty 1993).

Humanists' interest in the subject of cultural diversity resulted directly from the whole group of dynamically interrelated changes occurring in Europe and creating a new social-cultural situation. The collapse of old political \& administrative structure led to the formation of new autonomous state entities. The collapse of the former Yugoslavia, Soviet Union or Czechoslovakia must be mentioned here as key processes of deconstruction of old administrative \& state structures. Each of „emerging” states had to define its identity, as well as its relations with other states, both those "existing" and those "emerging". Until then, many of these structural sub-elements of larger wholes had been very dependent on one another. An example can be the policy of the Soviet Union, which was actually based on making individual republic dependent on the state so that they could not exist autonomously. This was carried out through the specialised allocation of industry, agriculture or processing to various republics, which forced them to co-operate and, at the same time, made the independent economic functioning of regions impossible. As a result of this policy, autonomous countries experienced a period of profound poverty, often preceded by actual armed conflicts, after the collapse of the Soviet Union. This enforced artificial dependence, which, however, ensured political peace.

Similar activities, but with completely different purposes, laid the foundations for the creation of the European Union after World War II. The mutual voluntary economic dependence of founding member states of the EU was to guarantee peace and mitigate potential attempts of individual countries to gain power at the expense of other countries (cf. Consolidated Version of the Treaty on European Union - http://oide.sejm.gov.pl/oide/index.php?option=com_content\&view=article\&id=14803\&Itemid=945). It was an idea originated by Jean Monnet and implemented by Robert Schumann - an idea of creation of a supranational union combining economic interests for the purpose of obtaining a peace relation that would prevent potential armed conflicts. As the name suggests (Latin: Unio - union), the process was aimed at creating one structure that would be an amalgamation of a few/many others. From today's perspective, we can see that while creating such union on the economic level, or even on the 
legislative level, can be easier, merging states into supranational structures in the cultural aspect is much more difficult ${ }^{1}$.

The collapse of the aforementioned old structures proceeded in a more or less peaceful manner; however, it forced individual states to redefine themselves. An opposite process was the gradual enlargement of the European Union, which admitted new member states. This reverse process also enforced in a natural way reflections on the adaptation of individual member states to the majority imposing rules, solutions and arrangements. The issues that would be regarded as central to the maintenance of national identity were subject to negotiations (the introduction of a common currency seemed to be the most important in this respect). In this way, each member state was confronted again with the question about its own identity, the method of defining it, the possibility of its change, etc. Each successive state joining the Union faces the same questions about the possibility of resigning from certain culturally important elements for the creation of unity with other member states.

Whereas both aforementioned megatrends of deconstruction and construction occurred in the context of the globalisation process, the entire phenomenon gained momentum and changes have been not only fast: their scope encompasses not only Europe, but basically the whole world. Obviously, the phenomenon that had a huge impact on the intensification of intercultural contacts in Europe was the collapse of the Berlin Wall, which made it easier and possible to establish contact between countries that knew virtually nothing about one another and enabled the transmission of cultural values and cultural artefacts from the "West" to the "East" and vice versa. All of these processes enforced a profound reflection on the problem of cultural diversity, increasing migrations and mobility. The policies worked out mainly in Australia, United States and Canada began to be transplanted to Europe. In particular, Canada became a place of dynamic development of humanistic thought connected with cultural diversity. Outstanding contribution to Canadian human science was made by intellectual proposals expressed by Will Kymlicka (1991) and Charles Taylor (1992, 1995, 1996). Those two thinkers laid

\footnotetext{
${ }^{1}$ In this context, it is worth mentioning the completely unique concept of Islamic umma - one supranational structure built on the basis of mutual religious beliefs, i.e., an axiological system indicating desirable and undesirable methods of behaviour expressing certain values. Umma unites Muslim states into a sort of informal cultural union, which is incomparably stronger than the European Union (in the cultural aspect) or any other sort of union, such as the League of Arab States. It should probably be assumed that umma is created on the basis of deeply internationalised respect for religion as an axial-normative code (cf. Huntington 1997).
} 
milestones for the development of thought related to multiculturalism, cultural diversity and the promotion of the policy of multiculturalism.

In Canada (as in Australia), the acceptance of cultural differences is inseparably connected with the need to compensate for losses suffered by ethnic minorities as a result of colonisation and cultural expansion by dominant cultures. The philosophical output of Will Kymlicka is centred around the political philosophy that focuses on the ensuring of equal social functioning to ethnic and national cultural minorities functioning within majority groups and is founded on basic disagreement to the exploitation of weaker societies. According to Kymlicka, the equal treatment of citizens belonging to minorities should be ensured by adapting existing rights to the specific nature of a society (he coined the term "group-differentiated rights", cf. 1995). What is meant here, is the assignment of certain group-differentiated rights arising in respect of belonging to a certain group (an example can be the exemption of certain groups from taxation or the assignment of rights to perform certain gainful activities to them; an example of such functioning is the right of the minority society of American Indians in the USA to conduct gainful activity in casinos). In this line of thought, the term "multiculturalism" must be treated as a broadly defined method of perception of socially and politically weak groups. Thus, although it is referred most frequently to thinking of nations/groups that are ethnically different from the majority, the broad perception of multiculturalism assumes the application of this term also to all other categories of exploited groups: enslaved groups (in case of slavery), subordinated groups (oppression towards women), discriminated groups (homosexuals) and many other "underprivileged groups"2. Interpreted in such a manner, the policy of multiculturalism has many dimensions; it is not only concurrent with reflections on identity (2000, Bauman 2004, Giddens 2002, Melosik and Szkudlarek 1998, Melosik 1996, Melosik 2002), with the identification policy (in terms of recognition of rights possessed by a given group) (cf. Ricoeur 1992 and 2004, Taylor 1992, Taylor 2001), but it also has an economic dimension. All of these dimensions are aimed at the re-evaluation of minority groups and the restoration of their status as members of society with full rights, in spite of their long-term exploitation and defining in terms of better-worse and weaker-stronger dimensions. The support of the idea of multiculturalism may result from different and basically opposite methods of argumentation. The most influential way of thinking about the policy of multiculturalism was formulated by Will Kymlicka on the basis of liberal values of equality and autonomy. From this perspective, culture is an individually useful tool, because

\footnotetext{
${ }^{2}$ It is worth noting that Will Kymlicki's philosophy includes also oppressively treated and exploited groups of animals, which are treated as individual beings with basic rights by him. These views are presented by him in Zoopolis (2011).
} 
it ensures the possibility of choosing behaviours, values and preferences from their entire scope, which is an inalienable condition for the maintenance and fulfilment of autonomous decisions. Culture is also the basis of creation of a sense of individual identity, because it is referred to the group in which an entity functions. Such a group is a sort of self-reflection in the mirror of other people, which forms a basis for reflections on auto-definition (this is, of course, concurrent with ideas of symbolic interactionism - cf. Mead 1975, Cooley - cf. Mucha 1992). Because these values ensured through participation in one's own cultural group are unavailable to communities (groups) that are treated worse in a society, these communities should receive special protection and should have rights other than possessed by the majority in order to make up for deficits in the possibilities of self-definition. These special rights should be granted to minorities, particularly if they find themselves in situations that have been generated without their participation, i.e., when they are not responsible for their own position as a result of their own causal activity leading to the existing situation of given groups. From this viewpoint, various minority groups should be treated differently and should be entitled to other rights: for example, the situation of autochthonous ethnic minorities (e.g., North American Indians) is entirely different from that of migrants arriving, e.g., in the USA. The former were incorporated into the majority group unintentionally and almost by force, whereas the latter joined this majority group of their own free will, as a result of active and conscious choices (Kymlicka 1989, 1995, 2001).

The perspective of treatment of multiculturalism proposed by Charles Taylor is embedded in the context of communitaristic perception of the world, where community efforts prevail over individual interests. The key element in this approach is the promotion of the identification policy - the recognition of the group as a valuable social structure with full rights; values and issues important for an entity are put aside and regarded as secondary (1992). The identification of minority cultures means that the principles of granting identical rights to everyone should be put aside and, instead, these rights should be differentiated depending on the social position and special rights necessary to improve the value of underestimated cultures.

The third of the possible perspectives - the postcolonial one - assumes that multiculturalism is based on searching for such models of dialogue that will appreciate various methods of behaviour (and valuation) embedded in various cultures. Modern societies are so diverse that even the adoption of a liberal perspective towards them should be conscious, i.e., it should result directly from the assumption that liberalism is one of many possible ways of looking at social reality. In this sense, liberalism is a reflection of the rules of a certain culture. Thus, values of liberal societies 
should be treated only as a starting point for the construction of more transcultural forms of communication between representatives of various cultures.

Descriptive approaches to the multicultural world made use of the rhetoric resulting from adopted metaphors. The metaphor of a "melting pot" that fuses various cultures into one whole is contrasted with "cultural mosaic", where various cultures co-exist on the basis of the preservation of autonomy and borders (in a metaphorical sense) while making a part of a larger whole. An example of the former would be the United States of America, whereas the latter would be represented by Europe, particularly its part forming the European Union. Then the metaphor of the "Balkan pot" appeared - it did not form a uniform amalgamate, as would be expected in the case of the melting pot. The Balkan pot is a constantly boiling content that may spill over or suddenly explode at any moment. The last of the descriptive cultural metaphors is the "salad bowl", which adds an extra dimension to the description of reality. Here, cultural structures mix together and form one dish, but they retain their original characteristics.

The promotion of multiculturalism and cultural diversity has already brought desired effects to a large extent. It became clear both for followers and opponents that it is an irreversible and inevitable process that dynamically changes the demographic social structure of the world. Thus, it can be basically said that beliefs of cultural diversity, its value and the inevitable intensification of this process are also firmly established in the field of serious human science. In spite of this, there is still much to develop in the field of broadly understood social acceptance. The most recent surveys concerning attitudes towards cultural diversity show that the situation is far from perfect in this respect and there are still large areas where cultural diversity is not socially accepted. A survey conducted by the Centre for Public Opinion Research (CBOS) in January 2016 that was stimulated by the arrival of refugees from Syria in Europe indicates: 'A majority of Poles (53\%, the same as last month) think that Poland should not accept any refugees whatsoever. Slightly more than two fifths of respondents (41\%) accept giving shelter to them in Poland; however, most of them (37\% of the total group) think that this should be done only until the moment when they can return to their country of origin. Only $4 \%$ of respondents think that we should accept refugees and allow them to settle in Poland.' (CBOS 12/2016 p. 1). Later, in the same message, we read: „The last significant increase in the share of respondents speaking in favour of closing borders for refugees was recorded after November terrorist attacks in Paris inspired by the Islamic State. Reports of November incidents in Cologne did not result in further deterioration of the attitude of Poles towards refugees. Results of the January survey are almost the same as December results' (CBOS 12/2016 p. 2). Results of pub- 
lic opinion polls reflect social facts accurately; cultural conflicts, particularly those involving violence (including weapons), are unequivocally reflected in statistics and research results. The following chart reflects the increase of Poles' unwillingness to accept emigrants, depending on what happened in the field of intercultural relations and what was reported by the media (CBOS 12/2016 p. 4).

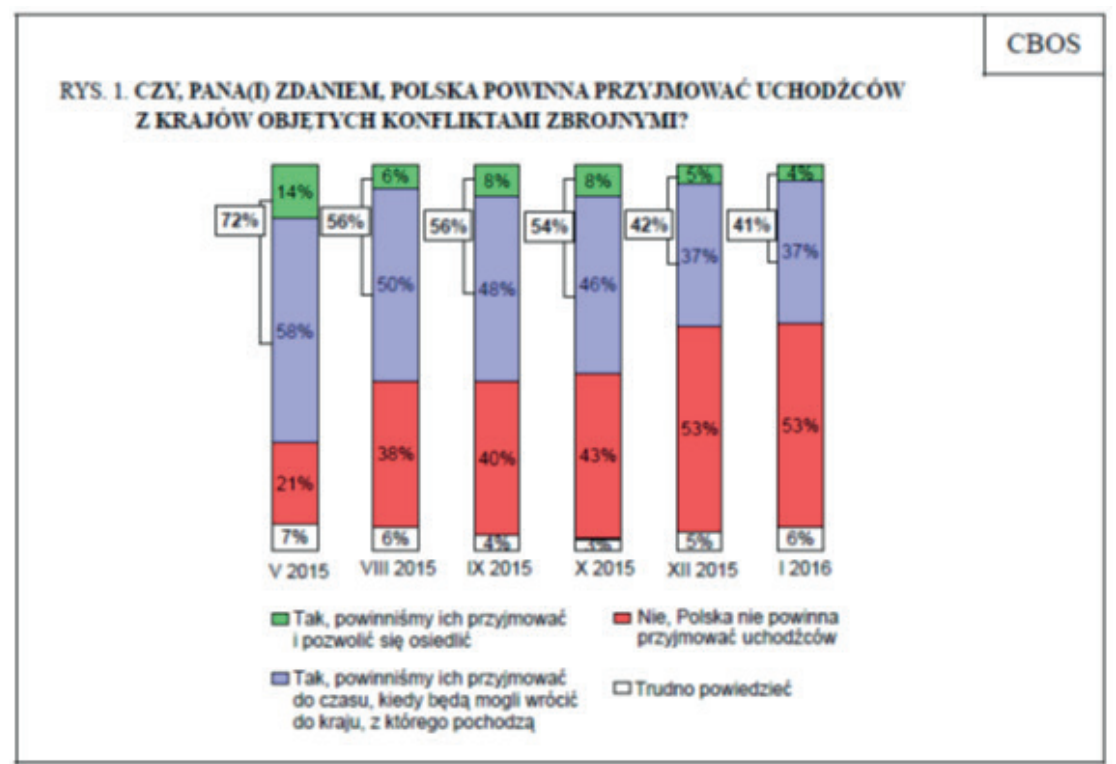

Fig. 1

DO YOU THINK POLAND SHOULD

ACCEPT REFUGEES FROM COUNTRIES

COVERED BY ARMED CONFLICTS?

Yes, we should accept them and allow them to settle

Yes, we should accept them until they can return to the country from which they come

No, Poland should not accept refugees

It is difficult to say

The authors of the message write: 'In comparison to December, the attitude towards refugees from the Middle East and Africa is almost unchanged, too. Almost every third respondent (30\%, the same as last month) thinks that Poland should accept part of refugees from these areas. Almost two thirds (63\%, decrease by 1 percentage point) object to this. However, it must be noted that the share 
of respondents strongly objecting to the acceptance of this group of refugees by Poland has been growing slowly but systematically since May 2015 (an increase by 3 percentage points during the last month). The approval of the acceptance of refugees from the Middle East and Africa grows with the respondent's age and the assessment of his/her own financial situation. It can be seen that such actions are approved more frequently among respondents with higher education (43\%) and those who declare leftist political views (49\%). The approval of the acceptance of part of refugees from these areas is expressed most rarely by the youngest respondents (aged between 18 and 24) and village inhabitants (20\%).' (CBOS 12/2016 p. 3).

In surveys conducted and presented within the European Social Survey, analogous trends can be observed with regard to openness to multiculturalism: 'As results of the ESS show, certain phenomena relating to attitudes towards immigrants are relatively permanent and constitute a repetition of trends appearing in the survey conducted thirteen years ago. First of all, respondents in European states participating in the ESS are more open to immigrants from European states than towards immigrants from non-European states. A similar tendency occurs in the case of questions about immigrants of the same or different race / ethnic group. Attitudes declared towards immigrants of the same race or ethnic group are more favourable than attitudes towards immigrants of the same race or ethnic group' (Andrejuk 2015 p. 2) ${ }^{3}$.

Discussing Polish results for the ESS, Andrejuk described accurately the social \& political background for two surveys conducted within thirty years. The author writes: 'Some questions were repeated and had already been asked in the European Social Survey from 2002, i.e., also in a moment that was particularly difficult in terms of multiculturalism: after terrorist attacks in the United States (2001) and related moral panic concerning Muslim immigrants. In the period between analysed rounds of the ESS, there were also events that may have had an impact on the openness, or lack of openness, of receiving societies towards immigrants: terrorist attacks in Madrid (2004) and London (2005), or the economic crisis that affected a majority of European states (excluding Poland) in 2009. In Poland, the context

\footnotetext{
${ }^{3}$ Respondents from 22 countries took part in the $7^{\text {th }}$ Round of the European Social Survey (data about 15 countries are available, and 7 countries have not published results yet). Some of the question were not asked in every country - e.g., some analyses do not include Czech Republic and Estonia if a given fragment of the questionnaire was omitted. Samples are selected at random and are representative of the structure of population of individual countries; respondents are persons at the age of 15 or more years (without the upper age limit); inhabitants of the country concerned are selected for the sample regardless of their nationality, national origin and language. In a majority of participating countries, the survey was conducted at the end of 2014 and at the beginning of 2015; in Poland, it was performed later from April to September 2015 (Andrejuk 2015 pp. 3-4).
} 
of questions asked in the latest edition of the ESS (2015) is different than thirteen years ago. The state joined the European Union in 2004; in connection with the opening of labour markets of individual member states, migration from Poland to member states of EU-15 became more intense. Apart from that, however, we also accept increasingly more economic immigrants from outside the EU. Significant changes were made in laws concerning foreigners to make it easier for them to live and work in Poland: the Act on the Pole's Card passed on 7 September 2007 made arrival in Poland and integration on the labour market easier for migrants of Polish origin from states of the former Soviet Union. The new amended Act on Foreigners came into force on 12 December 2013. Some changes after 2004 adapted Polish migration law to EU directives, e.g., by introducing the institution of a long-term resident.' (Andrejuk 2015 p. 5). This commentary to the results is extremely significant, because it explains the background for the process and places the results in the context of social \& cultural reality. It is surprising, against the background of these social events, how permanent (and hardly variable) results obtained in Poland are: 'The preliminary results of the survey show that Poland ranks in the middle of the scale, i.e., among European states with a moderately friendly attitude to immigrants' (Andrejuk 2015 p. 5). Commenting upon the results, the author emphasises that all countries reflect the same trend: the influence of migration on the culture of receiving countries is assessed much higher than the influence on economy. These results can be presumably interpreted as resulting from concerns about economic possibilities of native markets.

\section{Kultura kraju przyjmującego - zagrożona czy wzbogacona przez imigrantów? \\ (0-10, 0: bardzo zagrożona, 10: bardzo wzbogacona)}

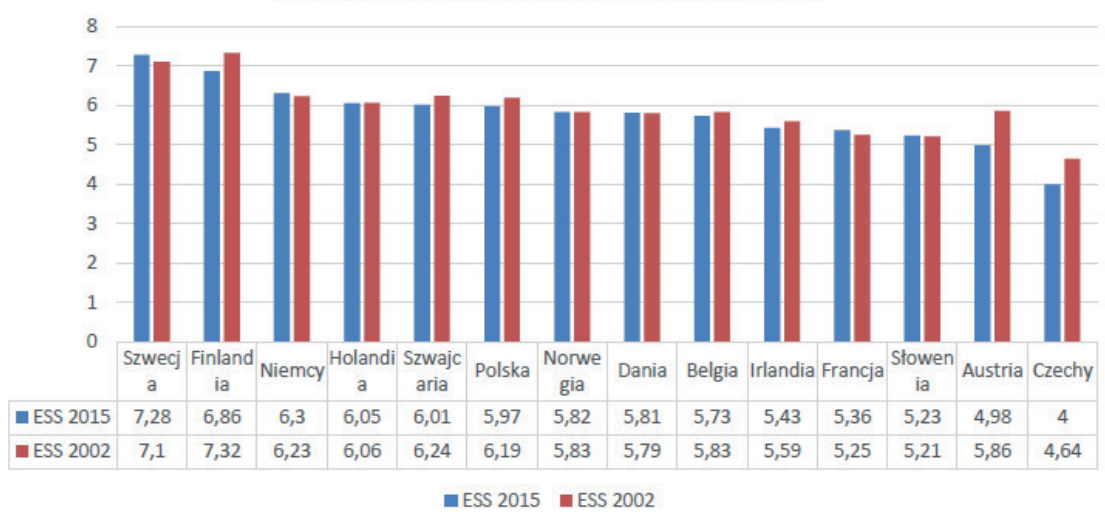


Imigracja - dobra czy zła dla gospodarki kraju?

(skala 0-10, 0: bardzo zła, 10: bardzo dobra)

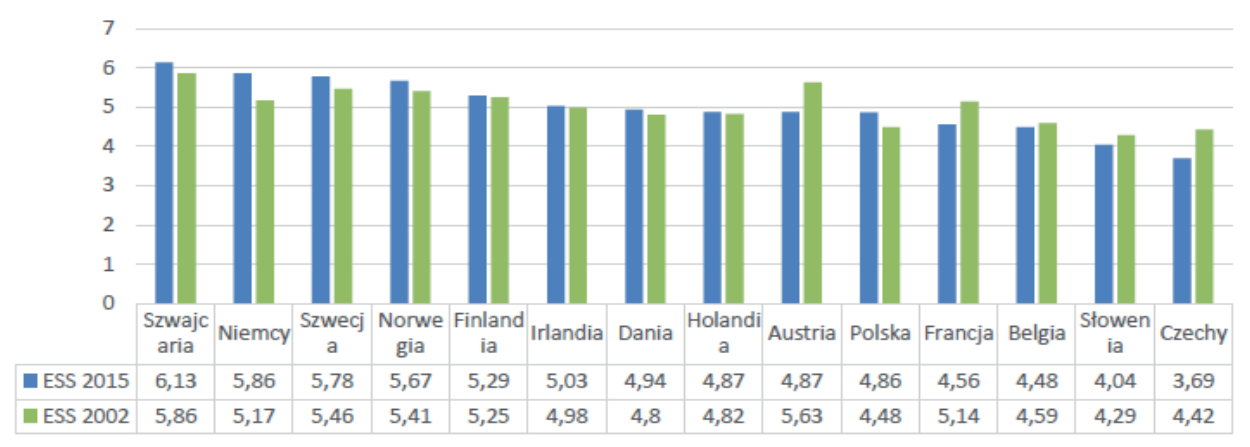

[ ESS 2015 모 ESS 2002

\begin{tabular}{|l|}
\hline $\begin{array}{l}\text { The culture of the receiving country: is it endan- } \\
\text { gered or enriched by emigrants? }\end{array}$ \\
\hline very endangered \\
\hline very enriched \\
\hline Sweden \\
\hline Finland \\
\hline Germany \\
\hline Netherlands \\
\hline Switzerland \\
\hline Poland \\
\hline Norway \\
\hline Denmark \\
\hline Belgium \\
\hline Ireland \\
\hline France \\
\hline Slovenia \\
\hline Austria \\
\hline Czech Republic \\
\hline Source: ESS 2014 -2015 and ESS 2002 \\
\hline $\begin{array}{l}\text { Immigration: is it good or bad for the country's } \\
\text { economy? }\end{array}$ \\
\hline very bad \\
\hline very good \\
\hline Scale 0-10 \\
\hline
\end{tabular}


Also the analysis of media discourse in the last six months shows that the problem of understanding for cultural diversity still requires large-scale activities. It must be added, however, that the dislike for cultural diversity is also stimulated by aggressive behaviours of ethnic and national minorities towards the majority (even if generalisations attributing these negative actions to the entire community are unjustified, they have a strong impact on the perception of minority groups). Media discourse and the selection of information are important for the broad public opinion and shape its attitudes. It can be expected, therefore, that the last media reports on terrorist attacks in 2016 (Istanbul and Brussels March 2016, Baghdad and Essen - April 2016, Orlando - June 2016, Nice - July 2016) will influence the perception of ethnic minorities and, consequently, the entire phenomenon of cultural diversity. At the same time, however, K. Andrejuk comments in the text quoted above: 'Data show that Poles' attitudes declared towards refugees are particularly open and friendly; in this respect, we lead among European states analysed in the survey, which should make Poland stand out among the European countries where dynamic changes in attitudes towards migrants occurred over 13 years dividing the editions of the ESS under discussion (2015 p. 14). It must be remembered, however, that these contacts with different cultures are rare in the ethnically homogeneous Poland: 'Respondents from Poland most often declared that they have no contact with them at all (57.3\%) or they have such contacts less frequently than once a month $(16,1 \%)$. On the other hand, $26.7 \%$ of respondents said that they have such contacts once a month or more frequently' (Andrejuk 2015 p. 17). Undeniably, however, current events, particularly those with a negative message presented via mass media, effectively reduce the level of friendly attitude towards foreigners. Thus, there is still the question what strategies of action should be undertaken in the case of awareness of the irreversibility of the cultural diversity process on the one hand and clear signs of the collision of civilisations on the other hand (which was foretold by Huntington as early as 2007).

On the level of sociological analysis, we can see here a classic conflict of values that makes it impossible to build understanding between both parties to the conflict, because it turns out that, apart from positive attitude and awareness of one's own ethnocentrism, other tools are also needed to be able to build cultural understanding. On the level of social \& cultural practices, we can observe those that arouse not only the lack of acceptance, but a strong dislike and attempts to fight and resist them actively. The practices of this kind that meet with loud protests are, in particular, practices aimed at or based on the violation of the corporal integration of other people and animals (cf. the circumcision of girls, the Yulin Festival 
in China ${ }^{4}$ or the Gadhimai Festival in $\mathrm{Nepal}^{5}$ ). The observation of such practices prompts us to ask a very strong question about the limits of acceptability of cultural diversity and makes us realise that it is impossible to "accept everything" according to the "everything goes" principle. It turns out, therefore, that fears and resistances of a community accepting culturally different people cannot be put on the margin and classified as unjustified. Moreover, it seems necessary to assume that education towards multiculturalism should be based on the building of an attitude not only towards others, but also towards oneself. In this sense, the resistance expressed by communities against the acceptance of culturally different entities should be interpreted as a request for providing a tool that would allow both parties to co-exist safely. The need to consider this issue is becoming stronger in the context of most recent terrorist attacks, which confront even the most extreme supporters of cultural diversity with an important question how to take care of others, while taking care of oneself. Unfortunately, in the field of education towards multiculturalism, the postulate of "having a positive attitude to others" is strongly promoted without the possibility of assertive determination of one's own limits, which can be determined only on the basis of a profound reflection on one's own identity. There are very few projects supporting the determination of one's own tolerance limits in the field of education towards multiculturalism. These are the limits that allow us to accept otherness along with its cultural context, but in a manner that is also safe for the receiving entity. As a result of this, we can see increasingly frequent situations that suggest the helplessness of societies receiving migrants, as they are not equipped with any tools of protection: not only of their own identity, including cultural identity, but also their own physical integrity ${ }^{6}$.

\footnotetext{
${ }^{4}$ The Yulin Festival is connected with the Chinese tradition of eating meat, particularly on the occasion of the summer solstice day in Yulin, the capital of the Kuangs province. The festival arouses much controversy; on the one hand, it is deeply embedded in the Chinese tradition of eating dog meat. On the other hand, animals killed during the holiday lose their life in an extremely cruel way that is difficult to accept by representatives of Western culture and sensitive inhabitants of China (cf. Pawłowska A. http:// wyborcza.pl/1,148125,20097523,psy-sa-tluczone-palkami-potem-zostawiane-by-wykrwawily-sie.html date of access: 19 July 2016).

${ }^{5}$ The Gadhimai Festival is held every 5 years in the Bara district in Nepal. Animals from several species were killed there in a ritual way, including water buffaloes, pigs, goats, poultry and pigeons sacrificed to Gadhimai, the goddess of power. This festival was the most drastic religious holiday in the world. In 2015, religious leaders issued a statement suggesting that the holiday was officially forbidden. The festival gathered around 4 million people, and up to 0.5 million animals were killed (cf. http://www.peta.org/action/ action-alerts/urge-nepal-end-gadhimai-animal-massacre/ date of access: 19 July 2016).

${ }^{6}$ Here I mean situations of armed terrorist attacks in which people are killed and which cannot be stopped or effectively prevented by the receiving groups, which can actually act only post factum.
} 
In my opinion, it would be necessary to postulate in the current social \& political situation in the world the launch of educational programmes that are based on a slightly broader context preparing for challenges created by cultural diversity. I suggest that these projects should be based on the following assumptions:

- Building the awareness of cultural differences. Educational activities in this area are still necessary for the creation of the positive context of multicultural references. The awareness of the fact that cultures are diffusional (Golka 2007) is basically unequivocal, along with understanding that today's culture can no longer be defined in terms of traditional ethnic allocations closed within administrative borders. Unfortunately, such perception of culture is still common. It is, however, worth emphasising that today an adequate description of cultural phenomena must be embedded in definitions connected with theoretical approaches, such as the social \& regulatory conception of culture by Jerzy Kmita (Banaszak, Kmita 1991). In this case, culture is interpreted as a group of normative and prescriptive rules respected in a given community and is established in mental individual \& social awareness that is communicated intersubjectively to participants in social practice (cf. Kmita 1983). Such definition of culture allows us to separate it from the national \& ethnic dimension and gives the possibility of creating the context of understanding that depends on the broadly perceived perspective of modernity: flexibility, fragmentariness, permeability of borders and redefinability.

- Accustoming recipients to the fact that cultural diversity is an inevitable process and there is no escape from it. It would seem that much has already been said about that. Here, however, we also face the continuous presence of separatistic beliefs aimed at fulfilling individual ideas of separation from other cultural influences. Beliefs of this kind are visible in continuous attempts to separate unwanted communities from dominant communities physically. Examples of this are walls built for the purpose of restricting cultural impact, particularly by making migration difficult. Here, I mean physical walls (they have been built, for example, on the American-Mexican border, in Slovakia or in Bulgaria), but also the creation of formal \& legal barriers. I have already written elsewhere about the inadequacy of these attempts to erect real physical walls to social reality (cf. Mamzer 2014), but it is worth repeating that concepts assuming the possibility of physical separation of one nation from another sound infantile in post-industrial societies based on the processing of information. The only effective method of separation is to block the flow of information; this can really be effective to 
some extent (particularly if we agree with the assumption that post-industrial societies are based on the processing of information - the commonly criticised Internet control procedure in China is a good example here).

- Pointing out positive aspects of life in a culturally diversified society. Like any other level of diversity, cultural diversity undoubtedly carries a multitude of perspectives from which the world can be perceived. This diversity of perceptions allows them to enrich and supplement each other, and it is an undoubtedly huge resource that, when used skilfully, is an invaluable source of inspiration and critical analysis of actions being undertaken. In this case, the difficult aspect is to be able to manage diversity in an effective manner that utilises this diversity for the joint achievement of determined goals. Today, diversity management is becoming one of the more important competences not only in the tolerance building area, but also in areas related directly to human resources management.

- Identifying challenges resulting from cultural diversity. This area of activity does not seem to be occupied by critical and rational reflections made on the grounds of substantively applied human science. Instead of this, we can see media discourse based on common-sense assessments, the escalation of threats without suggesting possible methods of addressing such situations and the excessive highlighting of sensationalism of reports (cf. media reports concerning refugees' behaviours in Germany and "outrageously demanding attitudes of refugees" in Hungary and Austria in 2016). In order to manage multiculturalism rationally, it is necessary to identify and define these challenges and, at the same time, suggest practices that may serve as functional solutions or, at least, inspirations to look for them. There are many practical dilemmas of this kind; if they remain unsolved, they will inevitably contribute to an increase of animosity. Such potential sources of conflict may include dilemmas between requirements to put a personal photograph on identity documents and the prohibition to show one's face to outsiders in Islam. Various holidays related to different religious denominations that have an impact on relations between employees. Various modes of functioning during the day, depending on the religion or beliefs (e.g. the prayer time in Islam). There are also more subtle challenges: other behaviours promoted by the culture of origin and the culture of present life in the case of migrants (cf. Białas, Malewska - Peyre 2001), which indicated such conflict of expectations in the case of Muslim teenagers living in France. Thus, such challenges undeniably exist. The ability to identify and classify them as challenges rather than problems allows us to go to the next 
stage in the process of education towards multiculturalism, i.e., looking for alternative behaviours and possible solutions for these demanding situations.

- Determining the boundaries of "self". I have already begun dealing with this subject area in the context of intercultural education in another place (cf. Mamzer 2011). It seems, however, that still too little attention is paid to it. In the current social \& political situation, when migratory movements of refugees are becoming more intense, this seems to be one of the primary issues. Undertaking educational activities in this direction should provide majority groups with a sense of safety with regard to the integrity of one's own identity. The determination of these boundaries of the individual and group "self" is aimed at defining the indispensable elements of identity that are subjectively perceived as important for a given entity. It seems groundless to ignore the need for safety as one of the primary human needs that have already been defined by A. Maslow (1991).

- Building and promoting assertiveness teaching projects. On the individual level, the ability to defend one's preferences assertively gives a sense of safety and comfort and does not disturb the interlocutor's mental integrity. On the social level, this function of assertive behaviours is fulfilled by legislative arrangements that define objectively which behaviours are socially acceptable and which are not.

- Identifying value-based conflicts and developing competences to cope with them. This broad competence area refers largely to the reflective process of self-cognition and gaining the awareness of one's own cultural limitations, personal preferences and their background and role in subjective systems of values.

To sum up, the most important of these issues is, in my opinion, to guarantee a sense of safety to groups receiving representatives of other cultures. This is an inalienable guarantee of positive and open attitude to diversity. The verbalised and expressed sense of threat arising from the inflow of representatives of different cultures (but, primarily, as a result of their manifestation of behaviours that lead to situations based on conflicts of values) should not be treated as a sign of dislike, which is the most frequently quoted interpretation, or in terms of rejection; instead, it is worth looking at psychosocial mechanisms underlying such anxieties. This utterly basic mechanism can be anxiety for the possibility of maintaining one's own identity (also physical integrity, which actually stands for fear). The trivialisation of this anxiety and its reasons and its devaluation is an elementary error: failure to recognise its reasons makes it impossible to create strategies of its man- 
agement. These strategies should arise from educational programmes that meet existing needs: they allow people to develop adequately their competences that result in the tolerant attitude and are based on a strong sense of safety.

\section{References}

Andrejuk K. (2015). Postawy wobec imigrantów w świetle wyników Europejskiego Sondażu Społecznego 2014-2015. Polska na tle Europy. Working paper no. 2/2015. IFIS PAN. http://www.ifispan.pl/wp-content/uploads/2015/12/Postawy-wobec-imigrant\%C3\%B3w-w-\%C5\%9Bwietle-wynik\%C3\%B3w-Europejskiego-Sonda\%C5\%BCu-Spo\%C5\%82ecznego-2014-2015.-Polska-na-tle-Europy.pdf

Date of access: 19 July 2016

Banaszak, G., Kmita, J. (1991). Społeczno-regulacyjna koncepcja kultury. Instytut Kultury. Warszawa.

Bauman Z. (2000). Ponowoczesność jako źródło cierpień. Wydawnictwo Sic. Warszawa.

Bauman Z. (2004). Identity. Conversations with Benedetoo Vecchi. Polity Press. Cambridge.

Białas M., Malewska-Peyre H. (2001) (ed.) Swojskość i obcość: o akulturacji imigrantów w Polsce. Wydawnictwo Instytutu Psychologii PAN. Warszawa.

Burszta, W. (1995). Relatywizm i etnocentryzm postmodernistycznie widziane. In: A.Szahaj (ed.) Między pragmatyzmem a postmodernizmem. Wokół filozofii Richarda Rorty’ego, pp. 189-207. Uniwersytet im.M.Kopernika. Toruń.

CBOS 12/2016. Komunikat z badań. Stosunek Polaków do przyjmowania uchodźców.

Mucha J. (1992). Cooley. Wydawnictwo Wiedza Powszechna. Warszawa.

Giddens A. (2002). Nowoczesność i tożsamość, Wydawnictwo Naukowe PWN. Warszawa.

Golka M. (2007). Socjologia kultury. Wydawnictwo Naukowe Scholar. Warszawa.

Huntington S. (2007). Zderzenie cywilizacji. Muza. Warszawa.

Kmita, J. (1983). Kultura jako rzeczywistość myślowa. In: T.Kostyrko (ed.) Teoria kultury a badania nad zjawiskami artystycznymi, pp. 15-32. Centralny Ośrodek Metodyki Upowszechniania Kultury. Warszawa.

Kmita J. (1995). Rorty i Putnam wobec relatywizmu kulturowego. In: A.Szahaj (red.) Między pragmatyzmem a postmodernizmem. Wokół filozofii Richarda Rorty’ego, pp. 215-255. Uniwersytet im.M.Kopernika. Torun.

Kymlicka W. (1998). Współczesna filozofia polityczna. Społeczny Instytut Wydawniczy Znak. Kraków.

Kymlicka W. (1995) (red.), The Rights of Minority Cultures. Oxford University Press. Oxford.

Kymlicka W., Donaldson S. (2011). Zoopolis. A Political Theory of Animal Rights. Oxford University Press. Oxford.

Mamzer H. (2011). Adaptacja kulturowa a wytyczanie granic „Ja”. In: A.Paszko (2011) (ed.) Edukacja międzykulturowa w Polsce wobec nowych wyzwań, Kraków Stowarzyszenie Willa Decjusza, pp. 31-41.

Mamzer H. (2016). O wieloznaczności pojęcia mur. An unpublished text.

Maslow A. (1990). Motywacja i osobowość. Translated by P. Sawicka. Warszawa.

Mead G. (1975). Umysł, osobowość i społeczeństwo. PWN. Warszawa.

Melosik Z., Szkudlarek T. (1998). Kultura, tożsamość i edukacja. Migotanie znaczeń. Oficyna Wydawnicza Impuls. Kraków.

Melosik Z. (2002). Kryzys męskości w kulturze współczesnej. Wydawnictwo Wolumin. Poznań. 
Melosik Z. (1996). Tożsamość, ciało, władza. Teksty kulturowe jako (kon)teksty pedagogiczne. Wydawnictwo Edytor. Poznań- Toruń.

Ricoeur P. (1992). Filozofia osoby. Wydawnictwo Naukowe PAT. Kraków.

Ricoeur P. (2004). Drogi rozpoznana. Wydawnictwo Znak. Kraków.

Rorty, R. (1991). Objectivity, Relativism and Truth. Philosophical Papers, t.1. Cambridge University Press. Cambridge.

Rorty, R. (1993). Edukacja i wyzwanie postnowoczesności. In: Z.Kwieciński, L.Witkowski (ed.) Spory o edukację, pp. 96-103. Edytor. Toruń.

Taylor, C.(1992). “The Politics of Recognition". In: Multiculturalism: Examining the Politics of Recognition, A. Gutmann (ed.), Princeton: Princeton University Press.

Taylor, C (1995). Irreducibly Social Goods. In: Philosophical Arguments. Harvard University Press. Cambridge.

Taylor Ch. (1996). Etyka autentyczności. Społeczny Instytut Wydawniczy Znak. Kraków.

Taylor Ch. (2001). Źródła podmiotowości. Narodziny tożsamości nowoczesnej. Wydawnictwo Naukowe PWN. Warszawa.

Internet sources

Pawłowska A. (2016). Psy są tłuczone pałkami, potem zostawiane, by wykrwawiły się na śmierć. Festiwal psiego mięsa to festiwal okrucieństwa. http://wyborcza.pl/1,148125,20097523,psy-sa-tluczone-palkami-potem-zostawiane-by-wykrwawily-sie.html date of access: 19 July 2016.

http://www.peta.org/action/action-alerts/urge-nepal-end-gadhimai-animal-massacre/ date of access: 19 July 2016.

http://oide.sejm.gov.pl/oide/index.php?option=com_content\&view=article\&id=14803\&Itemid=945 date of access: 19 July 2016. 